\title{
The Attitude of socio-harmony and Local Wisdom: an Indicator of the Development of Social Tolerance of High School Students
}

\author{
Deni Adi Wijaya ${ }^{1}$, Djono $^{2}$, dan Suryo Ediyono ${ }^{3}$ \\ ${ }^{1}$ Graduate Program in History Education, Sebelas Maret University, Surakarta, Indonesia \\ ${ }^{2}$ Faculty of Teacher Training and Education Science, Sebelas Maret University, Surakarta, Indonesia \\ ${ }^{3}$ Faculty of Cultural Science, Sebelas Maret University, Surakarta, Indonesia
}

\begin{abstract}
This article discusses the dilematis aspect about the shift in traditional values-based local wisdom about the ecological aspects. Close to the learning in school emphasized the sides of cognitive ability and do not offset the granting of traditional values education. The purpose of this article is to promote tolerance of students to be more sensitive to the surroundings so as not to become individualists. Research results at the high school level, students are not given the attitude of socio-harmony in the form of tolerance. The purpose of this article is to enhance social tolerance that can deliver value to prevent the behavior concept asocial.
\end{abstract}

\section{Introduction}

This past decade, the educational paradigm switching to a pragmatist because of current globalization. Directly the values in traditional education replaced with instant education. Refer to the fact that resulted in terpinggirnya subjects of history because the students assume more importance facing the subjects examined in the national exam. Many cases of student fights, declining manners towards teaching system used due to gurus on cognitive and Psychomotor domains. Affective value no longer prioritized to build student character.

In the $21^{\text {st }}$ century this rapidly changing society accompanied social change in culture. These changes affect to the system of teaching the nuances of pattern that follows a pragmatic period, in this case the history teacher was forced to membelajarkan the material related to the world of work. As a result of learning history to be saturating and lost of charge values. Rapid cultural change caused a cultural globalization's influence can be seen in the development of students in a class. As one example of this is the phenomenon of the rate of development of the students ' positive attitudes formed through education at school is not as fast as the pace of development of the students ' negative attitude that is formed through the influence of modern teaching: hedonism, a materialistic, and idividualistis, of course it is not in accordance with the personality of the nation of Indonesia. It gives rise to a deterioration in moral values learners result from cultural changes leading to modernization. While local cultural values still exist though not commensurate with modernization that emphasize instant results. Values education can answer about the waning value of character and can build attitude of students through local wisdom values. It can be associated with the conclusion of researchers who stated, "Javanese people so protect and care about her children as contained in the proverbial Java Memayu Hayuning Bawana means add to the beauty of the world that's been created in such a beautiful". It is a tradition of values education has been used by instilling character values to students. 
Positive impact of advances in technology education indeed makes it easy for students to search for information such as on whatsapp, line, blackberry massengger, etc. The information is not all of it leads to positive things and the impact it makes students prefer communicating via digital than socialization. Changing the paradigm of communicating to the world of digital and tend to be more individualistic, American scientist D. Tapscott consider computerization becomes a measure of progress, intellectual capacity, and transforming the learning process (Naydenova \& Shaposhnikova, 2016).

\section{The issues socio-harmony and possible solution?}

One of the things that need to be examined is the problem egaliterianisme and reject the existence of social segregation in a multicultural society. This research highlights the crucial aspects of the traditional education of Javanese people are principled on the concept (1) memayu hayuning bawana means add to the beauty of the world with good works, (2) mangan ora mangan asal kumpul means everything despite not having anything required on the family group, respectively, and (3) rukun agawe santosa, crah agawe bubrah means that the pillars make safe peace and a sense of invidualistis make the split. Etymologically there are three Java language level is ngoko or coarse language, krama madya or fine language used to equal levels, and krama inggil or fine language used for someone who had degrees above. The Java community is therefore very much appreciate and respect each other, therefore socio-harmony so highly in tune with andap asor attitude or humble. Summed up each individual is very mindful of manners and culture Java very tolerance.

This way of thinking and behavior of Java against the influx of very elastic culture outside resulted in the creation of residential dwellings giving priority to harmony with elements of socio - harmonization between the implications of the establishment of the Joglo House with harmony with society. These elements created a development strategy to become a village "Gemah Ripah Loh Jinawi Tata Tentrem Kerta Raharja" Gemah Ripah Loh Jinawi Term etymologically refers to a region with fertility which brings prosperity, whereas Tata Tentrem Kerta Raharja described an area that is orderly, peaceful, and prosperous. The phrase is in tune with the founding of Javanese traditional House who prefer the harmonization as noted in the Serat Dewa Ruci, Haryanto (2007:11) argued, "the overall content of the Serat Dewa Ruci contains very valuable lessons about ethics and mysticism that until now the cultural values held by the people of Java". Therefore, the Javanese traditional house construction not only to stand upright but there are values and symbolic meanings.

The problem of socio-harmony high school level turns out to be in harmony with the local wisdom. The crucial problem, how students can absorb all local wisdom for personal development and social skills. It is the excellence of the students, in addition to being given a cognitive based learning also enriched the knowledge of social and personal knowledge. According to Titov \& Cherkashin (2016) knowledge is divided two ability-based Ecology, among others:

1. The ability of the emotional attitude, readiness of students in social activities;

2. Ecological knowledge Capabilities, allowing skills to troubleshoot the situation of ecology to form private student attitudes.

\section{Problem Solving?}

In the process of learning at the high school level, to improve the ability of personal and social students, teachers should design the class as there is in a society that is multicultural classes emphasize the similarities egaliterianisme students to reduce the asocial action leads to attitudes of discrimination. Teachers as facilitators of learning as a 
mediator to bridge their differences in class to avoid social segregation. This can be done by using the humanistic learning. As for the steps among others; 1) arrange the seating Division students to not clumped in one group alone but rather gives rise to a process of socialization, 2) gives the task group discussion by dividing the group into a heterogeneous.

\section{Socio-harmoni values and local wisdom}

In the context of Javanese culture, the term word often used to describe a harmonious society, harmonious Society (Balchindorzhieva \& Tsyrendorzhieva, 2016) means harmony between society and nature, individual and community, individuals and others, as well as individuals with her inner world. Thus giving birth to a social capital, (Ratanakosol, Pathumcharoenwattana, \& Kimpee, 2015) classified into six namely;

1) Human capital refers to the people, the example of the richness of local wisdom;

2) Commitment social relationships are formed within the community, such as rules and norms;

3) Natural capital, such as the environment's natural resources in the community;

4) Cultural capital;

5) Financial capital;

6) Capital base that is built as a facilities and infrastructure.

The purpose of the system of education is the development of cognitive, personal, social, and moral students. The hopes of researchers in this study in order to reduce the student's moral degradation due to globalization and to consider local characters such as example andap asor attitude or humble, with andap asor students can appreciate that life must respect differences. Specifically with the example of the attitude of the local characters who built in the expectation of history learning can improve social harmony students aligned with the principle of harmony of Javanese culture. Therefore the principle of Javanese people who actually is memayu hayuning bawana attitude which means where they live consider harmonization. Therefore students should be improved the attitude of social harmony in order to prevent the existence of a religious war raises the issue of tribe, race, religion, and war pose thought-provoking dissent that continuously lead to disintegration of the nation due to the pudarnya local culture as identity formation of character education. So, concluded the social harmony is the concept of respect for differences, mutually tolerant, accepting cultural diversity, Mahejabin (2015) describes indicators socio-harmony there 10 stages, among others;

1. Mutual understanding differences;

2. Developing social Harmony through cooperation;

3. Gender equality to decrease discrimination;

4. Social Tolerance;

5. Emphasize the love of the environment;

6. Social Harmony depends on the attitude of non-violence;

7. Humanism;

8. Respect for all religious, racial, ethnic, and tribal;

9. Emphasize social interaction;

10. The recognition of the values in the form of local wisdom of local communities. 
Development of indicators of social tolerance of high school students form social affective values, among other things:

Humanism;

$=$ attitudes to appreciate cultural diversity.

$=$ attitude of responsibility.

$=$ attitude of social skills in the form of socialization and social interaction in the form of courtesy, respect the differences between individuals in the community.

\section{Empathy;}

$=$ job skills in the form of mutual. solidarity against a friend

$=$ is experiencing a disaster.

= keep the natural environment as an attitude of maintaining continuity of society. such as preserving local wisdom.

\section{Tolerance;}

$=$ acknowledge diversity of religion, tribe, ethnicity, and race.

$=$ attitudes reducing social conflict.

Egalitarian;

$=$ gender equality be sexes form social discrimination not attitude

$=$ equation of culture, religion, race, and ethnicity.

The Value of Local Wisdom;

$=$ character's attitude reflected in the students an appreciation for cultural identity.

$=$ preserve relics of the forms of cultural discernment, wisdom in the form of social culture born in the community with nature, society and the individual, and the community with the creator.

\section{An alternative model of social inquiry to promote tolerance in Learning History}

The term learning already is best known in the world of education is issued UU RI No. 20 Year 2003 about the system of national education, UU Sisdiknas (2003: Article 1) stated:

Learning is defined as "... the process of interaction with educators and learners learning resources in an environment of learning". Learning as a concept of pedagogy, technically defined as the systematic and systemic effort to create learning environments that are potential yield learning process boils down to the development of individual potential as learners.

From that understanding, it appears that the learning and learning has a substantive and functional attachment, Winataputra argued, "the interconnectedness of substantive learning and learning is located on the node onset behavior change in individuals. The functional linkages with learning learning is to produce learning "(2007:1.1). About behavior change in learning behaviors can be associated with the conclusion of researchers who stated, "learning is the process of changing the behaviour (in the broad sense) incurred or modified through practice or exercise" (Chauhan, 1979:4). Regarding the substantive attachment in learning such affective side reflected the attitude of socio-harmony that is the attitude of tolerance and will peak later boils down to social tolerance awareness of students in an environment of family, school, and community. It can be associated with the conclusion of experts who declared, "learning is a series of activities of the soul in order to obtain a change in behavior as a result of the experience of individuals in interaction with the environment that concerns the cognitive, affective, and psychomotor" (Mayer, 2000:7). 
Learning History have aspects the purpose of skills development students to train a self-reliance and responsibility. On the other hand, the aspect of social values also need to be developed for the construction of the attitude of the character of students. One of the learning model used in this study using Inquiry model. Based on the opinion of Gulo quoted Al Tabany (2015:78) stated:

Inquiry strategy means a series of learning activities involve maximum throughout the students ' ability to find and investigate the systematic, critical, logical, analytical, so that it can formulate its own discovery. The main objectives of learning activity is Inquiry; 1) maximum student involvement in the process of learning activities, 2) keterarahan activities logically and systematically on the learning objectives, and 3) to develop an attitude of trust in themselves the students of what is found in the Inquiry process.

Based on explanation Inquiry learning in General turns out there is a special purpose. Massylas States Inquiry can improve skills to review the environment in more critical. The implications of learning History for training the critical thinking through the process of discovery. Regarding the advantages of learning in Inquiry model History, Widja (1989:49) argued, "method of Inquiry strongly support the strategy of teaching that emphasizes Local History material". It is when analyzed more deeply because the function Inquiry model could push students actively discuss relate to historical sources directly via the assignment in the group discussion. In addition, students are given an understanding of how the interpretation of the facts obtained using historical research include; 1) collection of historical sources/heuristics, 2) assessing and evaluating the collected facts/criticisms, 3) describes the style of the language's own historical sources obtained/interpretation, and 4) renders the analysis of a collection of facts through structured task/phase of historiography. The steps above when applied in the study of history should innovation with learning based on problems to train students skilled in problem solving. It was when combined with model Inquiry can create a learning situation problematic history, stimulus of students asked, curiosity and encourage students seeking answers through experimentation in the process of discussion. It can be associated with Bruner's opinion stated, "Discovery Learning can improve the cognitive skills of reasoning also trains students how to find and solve problems with knowledge and generate meaningful knowledge" (Winataputra, 2007:3.18).

From the above, the Exposure model learning of Inquiry has discussed the advantages according to experts and writers chose the social Inquiry model of Suchman. Richard Suchman developed a modified Inquiry learning. Suchman argues about the importance of bringing students on the attitude that all knowledge is tentative, an expert on education outlines a theory of Suchman as follows:

First, invite students to imagine in actual conditions;

second, identify the components that are around them;

third, formulate problems and making hypotheses on the condition;

fourth, get data by making the questions with answers "Yes" or "no";

fifth, make inferences from data acquired (Joyce in Al Tabany, 2015:85).

Based on the opinion of Bruce Joyce above, Social Inquiry is the learning strategies of social groups and subgroups of society. Students should be given experience of how to solve the problem, through the experience of each student will be able to build a useful knowledge for themselves and society. There are three characteristics of social Inquiry and strategy development formulated as follows:

First, the existence of social problems in the aspects of the class are considered important and can encourage the creation of class discussions; second, the formulation of the hypothesis as a focus for Inquiry; 
the third use of the fact as a hypothesis testing (Al Tabany, 2015:88)

In this study, learning learning stages using the syntax of Inquiry expressed by Eggen \& Kauchak (1996) that has been modified to researchers. Inquiry learning syntax can be seen in the table below.

Table 1. Inquiry Learning Stages

\begin{tabular}{|c|l|l|}
\hline Na & \multicolumn{1}{|c|}{ Phase } & \multicolumn{1}{|c|}{ Teacher Behavior } \\
\hline 1 & $\begin{array}{l}\text { Presenting questions } \\
\text { or problems }\end{array}$ & $\begin{array}{l}\text { Teachers guide students to identify a problem and the } \\
\text { problem is written on the Board and divide the students in } \\
\text { the group discussion. } \\
\text { Each group discussion should be evenly men, women, } \\
\text { tribal, ethnic origin and describes the multicultural } \\
\text { groups. }\end{array}$ \\
\hline 2 & Make a hypothesis & $\begin{array}{l}\text { The teacher gives the student the opportunity to argue } \\
\text { form the hypothesis. } \\
\text { Teachers guide students in determining the hypotheses } \\
\text { that are relevant to the issue. }\end{array}$ \\
\hline 3 & Designing experiment & $\begin{array}{l}\text { The teacher gives the student the opportunity to specify } \\
\text { the steps in accordance with the hypothesis. } \\
\text { Teachers guide students to sort steps the process of } \\
\text { discovery. }\end{array}$ \\
\hline 4 & $\begin{array}{l}\text { Experiment to obtain } \\
\text { information }\end{array}$ & $\begin{array}{l}\text { Teachers guide students get information through } \\
\text { discussion with other groups. } \\
\text { Teachers guide each group to try to solve problems } \\
\text { together. }\end{array}$ \\
\hline 5 & $\begin{array}{l}\text { Collect and analyze } \\
\text { data }\end{array}$ & $\begin{array}{l}\text { The teacher provides opportunities for each group to } \\
\text { present the data collected. } \\
\text { Teachers invite students to ask and guide all members of } \\
\text { the group to argue. }\end{array}$ \\
\hline 6 & Make inferences & $\begin{array}{l}\text { Teachers guide students in making conclusions are shared } \\
\text { equally between group discussions in class. } \\
\text { Teachers invite other groups to make a conclusion } \\
\text { beyond a group presentation. }\end{array}$ \\
\hline
\end{tabular}

\section{Conclusion}

Positive impact of advances in technology education indeed makes it easy for students to search for information. The information is not all of it leads to positive things and the impact it makes students prefer communicating via digital than socialization. Changing the paradigm of communicating to the world of digital and tend to be more individualistic. One of the things that need to be examined in the socio-harmony is a matter of egaliterianisme and reject the existence of social segregation in a multicultural society. The purpose of the system of education is the development of cognitive, personal, social, and moral students. Therefore students should be improved the attitude of social harmony in order to prevent the existence of religious wars cause problems the tribe, religion, and race. Specifically with the example of the attitude of the local characters who built in the expectation of 
history learning can improve social harmony students aligned with the principle of harmony of Javanese culture.

\section{References}

1. Al Tabany, T.I.B. Mendesain Model Pembelajaran Inovatif, Progresif, dan Kontekstual: Konsep, Landasan, dan Implementasinya Pada Kurikulum 2013, (2015).

2. Balchindorzhieva, O.B \& Tsyrendorzhieva, D.Sh. Harmonious Society and Ecological Civilization: The Concepts' Relationship, SHS Web of Conferences, 28, p.1-4 (2016).

3. Chauhan, S.S. Innovations in Teaching-Learning Process. (1979).

4. Eggen, P.D \& Kauchak, D.P. Strategies for Teachers Teaching Content and Thinking Skills, (1996).

5. Haryanto, S. Pembangunan Berwawasan Kultural. Senate Hearing Opens Inaugural Speech Professor, p.4-19 (2007).

6. Kemendikbud. Undang-Undang Republik Indonesia Nomor 20 Tahun 2003 Tentang Sistem Pendidikan Nasional, (2003).

7. Mahejabin. Social Harmony and Prosocial Behavior: Two Aspects of One Coin, Shaikshik Parisamvad An International Journal of Education, 5 (1), p.67-72 (2015).

8. Mayer, J.D. Emotion, Intelligence, and Emotional Intelligence. In Forgas, J.P. (Ed). The Handbook of Affect and Social Cognition, (2000).

9. Naydenova, N.N \& Shaposhnikova, T.D. Student in Information Society: Indicator of socio - moral Development of Individual in Quality Education Evaluation, $\underline{S H S W e b}$ of Conferences, 29, p.1-5 (2016).

10. Ratanakosol, K., Pathumcharoenwattana, W, \& Kimpee, P. Learning Process for Creating Community Identity, SHS Web of Conferences, 26, p.1-5 (2016).

11. Titov, E.V \& Cherkashin, E.I. Readiness of Senior Higher School Students for selfdetermination in Ecology Field as an ability to Form Subjective Attitude, $\underline{\text { HS Web of }}$ Conferences, 29, p.1-3 (2016).

12. Widja, I.G. Dasar - Dasar Pengembangan Strategi Serta Metode Pengajaran Sejarah, (1989).

13. Winataputra, U.S. Teori Belajar dan Pembelajaran, (2007). 